\title{
Association of TGFB3 rs2300607 (IVSI+ 5321) Gene Variant with Non Syndromic Cleft Lip/Palate in South Indian Patients
}

\author{
Varun Pratap Singh ${ }^{a}$, Dinesh Mysore Ramu. ${ }^{b}$, B.C. Amarnath ${ }^{c}$, R.M. Dharma ${ }^{\text {d }}$, Prashanth \\ Chikanayaka $^{\mathrm{e}}$, Akshai Shetty ${ }^{\mathrm{f}}$ \\ ${ }^{a}$ Department Of Orthodontics \& Dentofacial Orthopaedics, College of Dental Surgery, BP Koirala Institute of health \\ sciences, Dharan, Nepal. \\ ${ }^{\mathrm{b}}$ Professor \& Head, Department Of Orthodontics, D.A.P.M.R.V. Dental College, Bangalore, India \\ ${ }^{\mathrm{c}}$ Department Of Orthodontics, D.A.P.M.R.V. Dental College, Bangalore, India \\ ${ }^{\mathrm{d}}$ Department Of Orthodontics, D.A.P.M.R.V. Dental College, Bangalore, India \\ ${ }^{\mathrm{e}}$ Department Of Orthodontics, D.A.P.M.R.V. Dental College, Bangalore, India \\ ${ }^{\mathrm{f}}$ Department Of Orthodontics, D.A.P.M.R.V. Dental College, Bangalore, India \\ *Corresponding author \\ Dr. Varun Pratap Singh \\ Assistant Professor \& Incharge, \\ Department Of Orthodontics \& Dentofacial Orthopaedics, \\ College of Dental Surgery, \\ BP Koirala Institute of health sciences, \\ Dharan, Nepal. \\ Email: varundc@gmail.com \\ Telephone: +9779722555904 \\ Fax : +977-25-520251
}

Received: 28 April 2011; $\mid$ Revised: 15 May 2011; $\mid$ Accepted: 3 June 2011

\section{Abstract}

Introduction: Non Syndromic Cleft lip/Palate is a common congenital anomaly with significant medical, psychological, social and economic ramifications. It is an example of complex genetic trait. There is sufficient evidence to hypothesize that disease locus for this condition can be identified by candidate genes. The purpose of this study was to test whether TGFB3 rs2300607 (IVSI+ 5321) gene variant was involved in the etiology of Non Syndromal Cleft lip/Palate.

Materials and methods: Blood samples were collected with informed consent from 25 subjects having Non Syndromic Cleft lip/Palate and 25 controls .Genomic DNA was extracted from the blood samples, Polymerase Chain Reaction was performed (PCR) and digestion products were evaluated.

Results: The Results showed a positive correlation between TGFB3 rs2300607 (IVSI+ 5321) variant and Non Syndromal Cleft lip/Palate patients.

Conclusion: TGFB3 rs2300607 (IVSI+ 5321) gene variant may be a good screening marker for Non Syndromal Cleft lip /Palate.

Keywords: Non Syndromic Cleft lip and palate, TGFB3 rs2300607 (IVSI+ 5321) gene variant, Polymerase chain reaction. 


\section{Introduction}

The development of the head and face is one of the most complex and tightly controlled events during embryonic development. Disturbances during the period critical for the formation of face (7-10 weeks for humans) may lead to orofacial clefts. [1]

Cleft lip and palate is one of the most common congenital malformations. Immediately after birth, individuals with cleft lip/palate have facial deformities, feeding problems and frequent middle ear infections, the treatment of which requires interventions from multiple disciplines. At the age of speech acquisition, speech therapy is often needed to correct problems resulting from muscular defects of the clefts. As the individual continues to grow, defects in tooth development and malocclusion require dental and sometimes surgical treatment. The increased duration of treatment from birth to adult hood is a burden for the patient, family \& society.[2] Cleft Lip/Palate have a wide geographic distribution, with average birth prevalence in the world ranging from $1 / 300$ to $1 / 2500$ births. Approximately two thirds of the cases are not accompanied by other anomalies and are called non syndromic (NS). [1]

The etiology seems complex, but genetics plays a major role. Various candidate genes have been associated with Non Syndromal cleft lip/palate in different populations, but TGFB3 is strongly related in various populations on a consistent basis. TGFB3 is located on human chromosome 14q 24. It is expressed in the medial edge epithelium cells of palatal shelves and thought to contribute to palatal shelf elongation and fusions. Knockout mice studies with TGFB3 deletion have shown development of cleft palate. [3]

The mutations and polymorphisms of TGFB3 have been shown to be diverse. One of variation for TGFB3 is rs2300607 (IVSI+ 5321).[4] The advents of molecular biology and advanced genetic techniques have allowed uncovering, characterizing and ultimately manipulating the genes that make up the genome. It is becoming clear that the molecular centre of embryogenic morphology resides at the level of gene, in particular within families of the gene that encode transcription factors capable of regulating downstream gene transcription. It is important for the clinicians to keep abreast with these developments. Therefore it is necessary to study about these genetic variations to elaborate our understanding of the genetic control in various craniofacial determinants. In the present study, the focus of interest is to study the relation of TGFB3 rs2300607 (IVSI+ 5321) gene variant to Non Syndromal Cleft Lip/Palate. This helps in understanding the etiology of Non syndromal Cleft Lip / Palate so as to predict its occurrence and also to target at the molecular level for correction of such problems in the future.

\section{Materials \& methods}

The sample consisted of 25 subjects reporting to the cleft clinics of department of orthodontics and dentofacial orthopedics, D.A.P.M.R.V. Dental \& Hospital, Bangalore, Karnataka, India and 25 unrelated controls. Written informed consents were obtained from all subjects .The study was carried out after approval from institutional ethical committee and guidelines from Helinsiki declaration were followed. Subjects were grouped into two groups based on the presence of Non Syndromal Cleft Lip/Palate. Group A: Twenty five subjects with Non Syndromal Cleft Lip/ Palate, Group B: Twenty five control subjects. A thorough clinical examination was done. Patients having Cleft lip/palate associated with any History of developmental disabilities, including learning disabilities and attention deficits, hearing impairment, and speech deficits or abnormalities were excluded from the study. [5, 6]

Blood samples $(1.5 \mathrm{ml})$ were obtained from both Subjects and controls. Genomic DNA was extracted from the blood of the subjects by using ethanol, chloroform treatment. Once the isolated genomic DNA precipitate is obtained, it was used as a template for the polymerase chain reaction (PCR) test. The TGFB3 gene was amplified by PCR. The primers used in this study were procured from New England Laboratories, USA having the following base pair sequence. GGTTTAAACATTGTTTTGGC.[3] The PCR product (404 [bp]) thus obtained was run on $1.5 \%$ agarose gel containing ethidium bromide to assess the initial amplified PCR products. The amplified 
PCR products were digested with the specific restriction enzymes Apo 1 at $37^{\circ} \mathrm{C}$. The method adopted for PCR was Restriction Fragment Length Polymorphism (RFLP).The digested PCR products were separated into channels on a $1.5 \%$ agarose gel containing ethidium bromide in an electrophoretic chamber. A U.V.transilluminator was used to see the specific bands of base pairs of the digested PCR products [4].

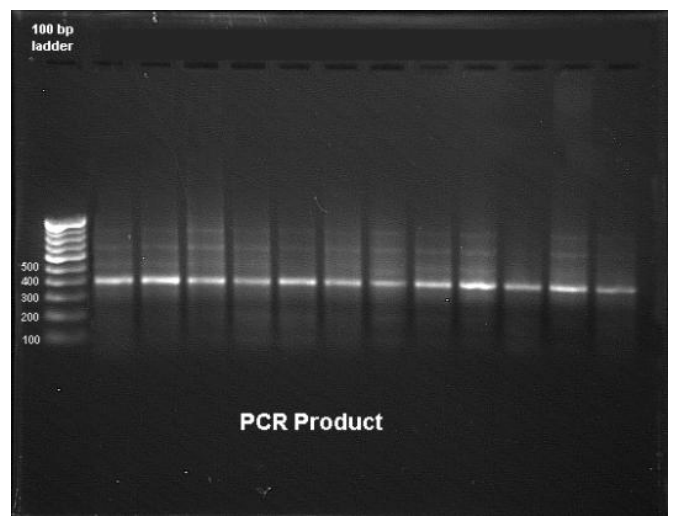

Figure 1. Initial PCR Product of TGFB3 gene (404bp).

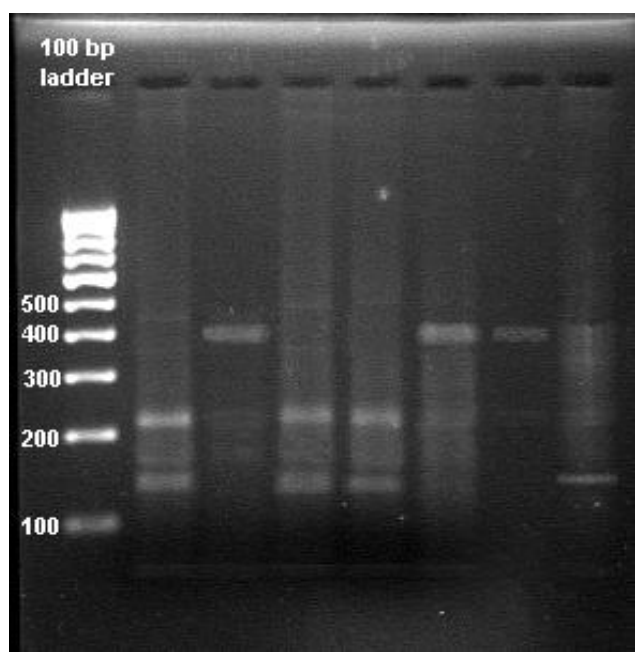

Figure 2. PCR products of TGFB3 after restriction with Apo1.

\section{Results}

The initial PCR product of the TGFB3 gene was obtained for the fifty subjects.The size of this PCR product was 404bp. (Fig.1). After obtaining the initial PCR products of TGFB3 gene (404 bp) from groups $\mathrm{A}$ and $\mathrm{B}$, samples were then subjected to digestion with the specific restriction enzyme Apo1. After digestion, the 404 bp products were completely digested with two restriction sites and three specific bands of 214,140 and 50 bp in 15 subjects of Group A whereas all subjects in Group B showed incomplete/no digestion. (Figure 2) So the presence of variant was shown only in 15 subjects of Group A and none in group B.

\section{Discussion}

Identification of the genes involved in the development of the human craniofacial region can serve as a first step towards developing a better understanding of diagnosis, treatment and preventions of developmental anomalies of this regions.[7] The genetic background of Non Syndromal cleft lip/palate is complex and most causes remain yet to be identified.

The process of palatal fusion is also controlled by interactive signaling from the mesenchyme to the epithelium which is mediated by growth factors and extracellular matrix (ECM) proteins. One of the key components in this process is TGFB3 expression which coordinates palatogenesis. (Britto et al )[8] This gene(TGFB3) determines extracellular matrix protein accumulation by stimulating extracellular matrix protein neosynthesis thereby inhibiting many enzymes which are responsible for extracellular matrix protein degradation .( Blavier et al.)[9]This reduced activity of TGFB3 due to genetic variation may increase the risk for oral clefts. Consistent with this hypothesis, TGFB3 knockout mice studies have shown a developmental defect of secondary palate. (Proetzal et al,)[10]

In this study the presence of TGFB3 gene variant in a sample of 50 subjects was assessed. A significant association was seen in Group A Subjects with TGFB3 gene variant as compared to controls. These findings suggest that these gene variants have a role in the etiology of non syndromal cleft lip/palate in our population).This is in accordance with the studies done by Andrew C. Lidral etal in South American population[11], J.Suazo etal in Chilean population[12] . However this study is contrary to a study done by Andrew C. Lidral etal. in Philippines population[13] which 
may be due to genetic differences in that population.

In Group B it was observed that there was no association with the gene variant. In this study $40 \%$ of the cases having non syndromal cleft lip/palate did not show any of these gene variants .This may suggest the possibility of involvement of other genes as non syndromal cleft lip/palate is of polygentic nature and studies suggest that other genes like TGFB3, RARA, BCLX3, TGF $\alpha A$, MTHR, PVLRI [1, 14] are involved in the etiology of non syndromal cleft lip/palate.

\section{Conclusion}

This study indicates that there is strong association between the presence of TGFB3 rs2300607 (IVSI+ 5321)gene variant with the incidence of non syndromal cleft lip and palate and it may act as a genetic marker for non syndromal cleft lip and palate in this population.

Studies about such genetic markers of non syndromic cleft lip and palate will help us to predict and target at the molecular level in treating such problems. A major challenge is not only a complete cataloguing of all such genes involved in the etiology of non syndromal cleft lip palate but identification of their polygenetic nature to have a thorough understanding of the craniofacial development. The future challenge is to bring this new knowledge from the "level of PCR sequencer into the clinical realms".

\section{Acknowledgements}

The authors are grateful to Dr. K.S. Nagesh Principal \& Chairman and other members of Ethical \&Scientific Committee of D.A.P.M.R.V. Dental College \& Hospital for approval and Genohelix Biolabs where the genetic analysis was performed. Authors thank Mr. Sandeep of Genohelix, Dr Malcolm Moore for English language corrections, Dr. Rakesh Rao for his valuable suggestions.

\section{References}

1. Morkuniene, A.; Steponaviciute, D.; Ambrozaityte, L.; Utkus, A.; Linkeviciane, L.; Kucinskas,V. TGFA, TGFB3, GABRB3, RARA and BCL3 loci associated with nonsyndromic orofacial clefts? A Lithuanian study, Biologija, 2007,18(1),1-6

2. Wong, F.K.; Hagg, U. An update on the aetiology of orofacial clefts, Hong Kong Med J ,2004,10 (5), 331-336.

3. Reutter, H.; Birnbaum, S.; Mende, M.; Lauster, C.; Schmidt, G.; Henschke, H.et al. TGFB3 displays parent-of-origin effects among cevasilntral Europeans with nonsyndromic cleft lip and palate, J Hum Genet,2008, 53,656-661. DOI 10.1007/s10038-008-0296-9.

4. Morkuniene, A.; Kueinskas, V. Validation and selection of an informative set of singlenucleotide- polymorphism in the TGFB3 genes, Acta Medica Lituanica, 2005, 12 (2),17.

5. Mitchell, L.; Beaty, T.H.; Lidral,A.C.; Munger, R.G.; Murray, J.C.; Howard, M.S.; Wyszensi, F.D. Guidelines for the Design and Analysis of Studies on Nonsyndromic Cleft Lip and Cleft Palate in Humans: Summary Report From a Workshop of the International Consortium for Oral Clefts Genetics Cleft Palate-Craniofacial Journal, 2002, 39(1), 274278

6. Khoury, M.J. Nontraditional epidemiologic approaches in the analysis of geneenvironment interaction: case-control studies with no controls! ,Am J Epidemiol, 1996,144,207-213

7. Chang, H.; Yen, S.; Kim, R.E.Genetic analysis of the mammalial transforming growth factorBeta Superfamily, Endocrine reviews, 2002, 23(6), 787-823. DOI 10.1210/er.2002-0003.

8. Britto, J.A.; Evans, R.D.; Hevard, R.D.; Jones, B.M. Towards pathogenesis of apert cleft palate: FGF, FGFR and TGFbeta genes are differently expressed in sequential stages of human palatal shelf fusion, Cleft palatecraniofacial journal, 2002, 39(3),671-676. DOI: $10.1597 / 1545-1569(2002) 039<0332$ : TPOACP $>2.0 . \mathrm{CO} ; 2$ 
9. Blavier, L.; Lazaryev, A.; Groffen, J.; Heisterkamp, N.; Declerck, Y.A.; Kaartinen, V. TGF Beta3- induced palatogenesis requires matrix metalloproteinases, Molecular biology of the cell 2001, 12, 1457-1466. PMid:11359935 PMCid:34597

10. Proetzel,G.; Pawlowski,S.A.; Wiles,M.V.; Yin,M.; Boivin,G.P.; Howles,P.N. etal. Transforming growth factor/Beta3 is required for secondary palate fusion, Nature genetics 1995, 11, 409-414. DOI:10.1038/ng1295-409

11. Lidral,A.C.; Romitti,P.A.; Basart,A.M.; Doetschman,T.; Leysens,N.J.; Hirsch,S.D.etal. Association of MSX1 and TGFB3 with nonsyndromic clefting in humans, Am. J. Hum. Genet, 1998, 63, 557-568. DOI: $10.1086 / 301956$
12. Suazo,J.;Santos,M.J.;Carreno,H.;Jara,L.;Blanc o,R. Linkage Disequilibrium between MSX1 and Nonsyndromic Cleft lip/palate in the Chilean population, J Dent res, 2004, 83(10), 782-785. DOI 10.1177/154405910408301009.

13. Lidral, A.C.; Romitti, P.A.; Basart, A.M. Studies of the Candidate genes TGFB2, MSX1, TGFA and TGFB3 in the etiology of Cleft lip and palate in the Philippines, Cleft Palate. -Craniofacial journal, 1997, 34(1), 557-568. DOI:10.1597/1545-1569(1997)034 $\leq 0001:$ SOTCGT $>2.3 . \mathrm{CO} ; 2$

14. Jagomägi, T.; Nikopensius, T.; Krjutskov, K.; Tammekivi, V.; Viltrop, T.; Saag, M.; Metspalu, A. MTHFR and MSX1 contribute to the risk of nonsyndromic cleft lip/palate, Eur J Oral Sci, 2010, 118(3),213-220. DOI:10.1111/j.1600-0722.2010.00729.x 